\title{
SIMULATED YIELD AND NET RETURN OF A MAIZE CROP FERTILIZED WITH DIFFERENT SOURCES AND RATES OF NITROGEN
}

\author{
CAMILO DE LELIS TEIXEIRA DE ANDRADE ${ }^{1}$, TALES ANTÔNIO AMARAL ${ }^{2}$, \\ JASON DE OLIVEIRA DUARTE ${ }^{1}$, JOÃO CARLOS GARCIA ${ }^{1}$, \\ DENISE DE FREITAS SILVA ${ }^{1}$ and PAULO CÉZAR MARTINS ${ }^{3}$
}

\author{
${ }^{1}$ Embrapa Maize and Sorghum, Sete Lagoas, MG, Brazil, camilo.andrade@embrapa.br, jason.duarte@embrapa.br, \\ joao.garcia@embrapa.br,denisefreitassilva@oi.com.br \\ ${ }^{2}$ UFPel, Pelotas, RS, Brazil, tales_aamaral@yahoo.com.br \\ ${ }^{3}$ State Extension Service Agent for the city of Fortuna de Minas, Fortuna de Minas, MG, Brazil, fortuna.minas@emater.mg.gov.br
}

Revista Brasileira de Milho e Sorgo, v.11, n.3, p. 254-267, 2012

\begin{abstract}
The goal of this study was to evaluate yield and net return of a maize crop fertilized with different rates of conventional mineral fertilizer and cattle manure. The CSM-CERES-Maize model was used to simulate the nitrogen (N) fertilization management scenarios. Twelve treatments were simulated as follows: T1, T2 and T3 were, rates of 90, 130 and $160 \mathrm{~kg} \mathrm{ha}^{-1}$ of N as conventional fertilizer, respectively; T4a, T4b and T4c were $4.5 \mathrm{t} \mathrm{ha}^{-1}$ of air-dried cattle manure, rated at 17.05, 22.73 and 34.09 US\$ per ton, respectively; T5a, T5b and T5c were $6.5 \mathrm{t} \mathrm{ha}^{-1}$ of air-dried cattle manure, rated at US\$17.05, US\$22.73 and US\$ 34.09 per ton, respectively; T6a, T6b and T6c were 8.0 t ha $^{-1}$ of air-dried cattle manure, rated at US\$17.05, US\$22.73 and US\$ 34.09 US\$ per ton. It was assumed that the air-dried cattle manure has $2 \%$ of $\mathrm{N}$. The conventional mineral fertilization with a nitrogen rate of $90 \mathrm{~kg} \mathrm{ha}^{-1}(\mathrm{~T} 1)$ resulted in an average yield of 4.812 $\mathrm{kg} \mathrm{ha}^{-1}$ and average profitability of US\$ $35.56 \mathrm{ha}^{-1}$, while higher nitrogen rates caused economic losses. Profitabilities of US\$ 120.90 and US\$ $183.50 \mathrm{ha}^{-1}$ were obtained with cattle manure rates of 6,500 and 8,000 $\mathrm{kg} \mathrm{ha}^{-1}$, respectively. Key words: Zea mays L., fertilizer management, simulation, DSSAT, profitability.
\end{abstract}

\section{RENDIMENTO E RENTABILIDADE SIMULADOS DO MILHO ADUBADO COM DIFERENTES FONTES E DOSES DE NITROGÊNIO}

RESUMO - O objetivo deste estudo foi avaliar a produtividade e a rentabilidade de uma lavoura de milho adubada com diferentes doses de fertilizante convencional e de esterco bovino. O modelo CSM-CERES-Maize foi utilizado para simular cenários de manejo da adubação nitrogenada. Doze tratamentos foram simulados, como segue: T1, T2 e T3 foram doses de 90, 130 e $160 \mathrm{~kg} \mathrm{ha}^{-1}$ de $\mathrm{N}$ como fertilizante convencional; T4a, T4b e T4c foram 4,5 $\mathrm{t}^{-1} \mathrm{de}^{-1}$ esterco de gado seco ao ar, com custo de U\$17,05, U\$22,73 e U\$34,09 por tonelada, respectivamente; T5a, T5b e T5C foram 6,5 $\mathrm{t} \mathrm{ha}^{-1}$ de esterco bovino com os mesmos custos por tonelada anteriores; T6a, T6b e T6c foram 8,0 tha ${ }^{-1}$ de esterco bovino com os mesmos custos por tonelada anteriores. Assumiu-se que o esterco bovino seco ao ar apresenta $2 \%$ de $\mathrm{N}$. A adubação mineral convencional, com uma dose de nitrogênio de $90 \mathrm{~kg} \mathrm{ha}^{-1}$ (T1), resultou em um rendimento médio de $4.812 \mathrm{~kg} \mathrm{ha}^{-1}$ e rentabilidade média de U\$35,56 por hectare, enquanto as doses mais elevadas de nitrogênio proporcionaram perdas econômicas. Rentabilidades de U\$120,90 e U\$183,50 por hectares foram obtidas com doses de esterco bovino de 6.500 e $8.000 \mathrm{~kg} \mathrm{ha}^{-1}$, respectivamente.

Palavras-chave: Zea mays L., manejo de fertilizantes, simulação, DSSAT, rentabilidade. 
In Brazil, it is considered a family farm the establishment that abide for the following requirements: does not hold, in any capacity, a land area larger than four fiscal modules; use mostly hand labor of his own family in the farm's activities; the family income comes predominantly from the farms economic activities; manage the business with his own family (IBGE, 2006).

Maize is cultivated in about $55 \%$ of the Brazilian family farms (Novo, 2000), but in most cases has a low yield mainly due to the use of a low level of technology. Fertilization has been considered the most limiting factor for increasing maize yield (Bull, 1993). Maize is very responsive to nitrogen fertilization (Bortolini et al., 2001) which is, however, the main factor that increases maize production costs (Silva et al., 2005).

Manure constitutes a source of nutrients for plants and can contribute to reduce maize production costs. Availability of this product has increased in Brazil with the intensification of animal production in confined systems (Assmann et al., 2007). In addition, it provides an opportunity for properly disposing of potential contaminant waste. Handling manure is much more complicated than handling mineral fertilizer. However, with the increasing cost of energy and mineral fertilizers there is a renewed interest in using manure as a source of nutrients to plants (Schröder, 2005). Considering the economic aspects, applying dairy cattle slurry at an average rate of $180 \mathrm{~kg} \mathrm{~N} \mathrm{ha}^{-1}$ per year and adding $90 \mathrm{~kg} \mathrm{ha}^{-1}$ of inorganic $\mathrm{N}$ per year resulted in an economic optimum fertilization for silage maize in Belgium.

Field trials have indicated the successful utilization of cattle manure for maize production (Silva et al., 2004; Gomes et al., 2005). A family dairy cattle operation under Brazilian conditions with 15 cows generates sufficient manure to produce 10 to 11 tons of organic compounds per month, consisting of a mixture of $40 \%$ of solid manure, $57 \%$ of plant debris and straws and 3\% by weight of natural phosphate (Konzen, 1999). According to Kiehl (1985), the average nitrogen $(\mathrm{N})$, phosphorus $\left(\mathrm{P}_{2} \mathrm{O}_{5}\right)$ and potash $\left(\mathrm{K}_{2} \mathrm{O}\right)$ content in dry cattle manure is $19.2,10.1$ and $16.2 \mathrm{~kg} \mathrm{t}^{-1}$, respectively.

Crop simulation models can be highly efficient tools to investigate the effects and interactions of cattle manure with different crop management strategies. The Cropping System Model (CSM)CERES-Maize is one of the models that have been used by researchers in different parts of the world, for a wide range of applications (Jones et al., 2003; Soler et al, 2007; Hoogenboom et al., 2009). Among other processes, the model can simulate the turnover of soil organic matter and the decay of crop residues with the associated mineralization and, or immobilization of nitrogen, in addition to estimate nitrification of ammonium and nitrogen losses related to the denitrification processes (Godwin \& Singh, 1998). Long-term simulations using historical series of weather data allow the evaluation of the effect of interannual climate variability on crop performance. Data on yield and net return for a farm or production system are generated.

The CSM-CERES-Maize model was successfully applied to evaluate the effect of management and continued use of manure on organic $\mathrm{N}$ content, mineralization, maize uptake and leaching (Hoffmann \& Ritchie, 1993). A system called Animal Waste Management Program (AWMP) was linked to CERES-Maize and used to evaluate the effect of different scenarios of manure management on yield, uptake and leaching of nitrogen and organic matter decomposition (Shayya et al., 1993). 
The goal of this study was to evaluate the combined effect of weather variability and production costs and prices fluctuations on maize yield and net return for different rates of conventional mineral fertilizer (MF) and cattle manure (CM) for the Central Minas Gerais State, Brazil.

\section{Materials and Methods}

The studies were performed with the Crop Simulation Model (CSM)-CERES-Maize, one of the models of the Decision Support System for Agrotechnology Transfer (DSSAT), version 4.5 (Hoogenboom et al., 2009). The tool was used to simulate maize yield and net return for different scenarios of fertilization management with conventional mineral fertilizer and cattle manure as a nitrogen source.

Cultivar coefficients, as described in the model's cultivar file, for the single-cross maize hybrid, BRS 1030, had been previously calibrated (Santana et al., 2010). The adjusted values for maize genetic coefficients P1, P2, P5, G2, G3 and PHINT (Jones et al., 2003), were 263.80, 0.50, 1034.00, $648.00,5.14,44.22$, respectively. A series of 49 years of daily weather records, starting in 1960, containing data for precipitation, minimum and maximum air temperature and sunshine hours, was used as input in the model. It was also considered in the simulations the average attribute values for a Very Clayey Red Oxisol (Panoso et al., 2002) that represents a typical soil profile of the Brazilian Cerrado ecosystem (Table 1).

Since the simulations were set to start in July $24^{\text {th }}$, a very dry season in Southeastern Brazil, it was assumed that the initial soil-water content was close to the lower limit of available water. Since the soil under Cerrado vegetation has an average of $2.5 \%$ of

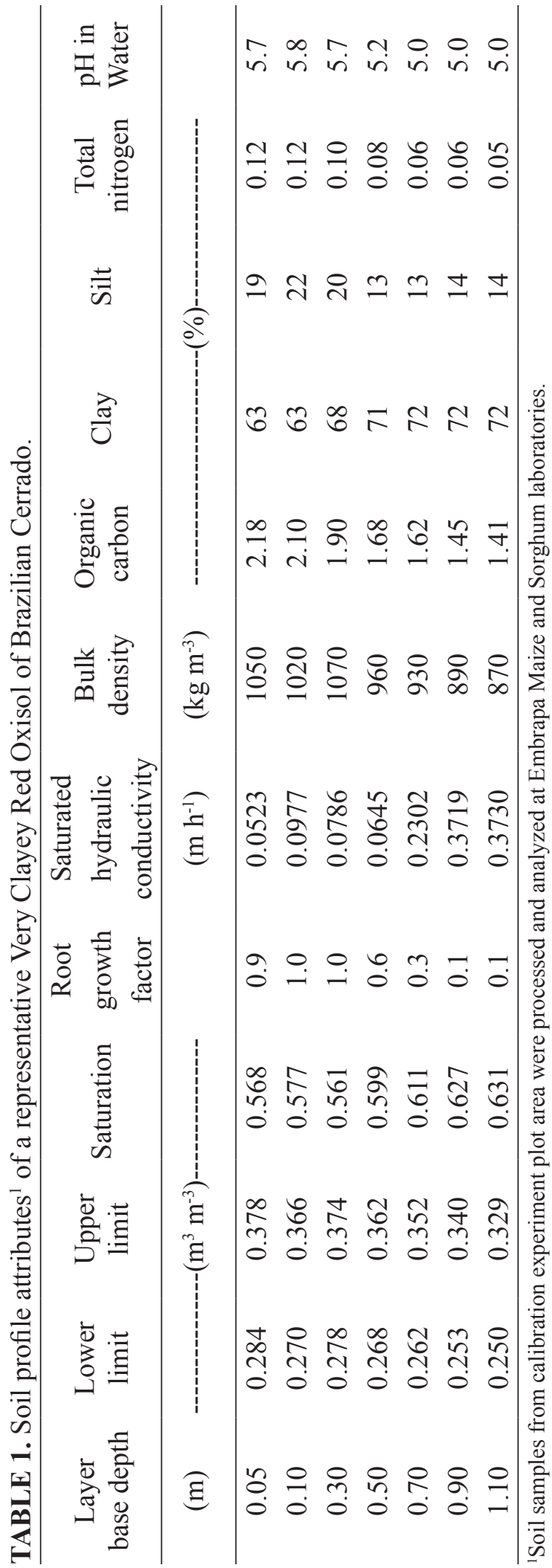


organic matter (Souza \& Lobato, 2002) and that, for each $1 \%$ of organic matter, the soil provides $30 \mathrm{~kg}$ $\mathrm{N} \mathrm{ha}^{-1}$, we considered as an initial condition in the simulations that the soil was capable of supplying an average of $50 \mathrm{~kg} \mathrm{ha}^{-1}$ of inorganic nitrogen to the crop, which was automatically converted by the model into nitrate and ammonium concentrations in the soil profile (Table 2). yield evaluation, six treatments were simulated that included three rates of conventional mineral fertilizer (MF) and three rates of cattle manure (CM). The mineral fertilizer was banded $8 \mathrm{~cm}$ deep at sowing. Two nitrogen side-dressings were applied to the MF treatments only, both banded on the soil surface. Urea was used 30 days after sowing (DAS) and ammonium sulfate was applied at 45 DAS. For

TABLE 2. Soil initial water content ${ }^{1}$ and nitrate and ammonium concentrations ${ }^{2}$ of the studied soil area.

\begin{tabular}{cccc}
\hline Layer base depth & Water content & \multicolumn{1}{c}{$\mathrm{NH}_{4}^{2}$} \\
\hline$(\mathrm{m})$ & $\left(\mathrm{m}^{3} \mathrm{~m}^{3}\right)$ & $\left(\mathrm{mg} \mathrm{kg}^{-1}\right)$ & $\left(\mathrm{mg} \mathrm{kg}^{-1}\right)$ \\
\hline 0.15 & 0.287 & 0.5 & 4.3 \\
0.30 & 0.264 & 0.5 & 4.3 \\
0.45 & 0.300 & 0.5 & 4.3 \\
0.60 & 0.294 & 0.5 & 4.3 \\
0.90 & 0.289 & 0.5 & 4.3 \\
1.20 & 0.300 & 0.5 & 4.3 \\
\hline
\end{tabular}

${ }^{1}$ Since simulations started in July 24 of each year, it was assumed that the soil initial water content was close to its lower limit of available water. ${ }^{2}$ Recalculations done by the model assuming that the soil was capable of supplying $50 \mathrm{~kg} \mathrm{ha}^{-1}$ of $\mathrm{N}_{\text {. }}$

Simulated sowing date was considered October $24^{\text {th }}$ of each year, since this is the date that provides the best average yield for maize grown under rainfed conditions for Central Minas Gerais region (Amaral et al., 2009). The maize hybrid BRS 1030 was sown at a depth of $6 \mathrm{~cm}$ with a row spacing of $0.8 \mathrm{~m}$ and plant density of 59,200 plants $\mathrm{ha}^{-1}$. The simulations were set to start at three months prior to sowing, so that the model simulated the soil water and nitrogen balance for a fallow soil in order to estimate more realistically the soil water content at planting

To determine the yield and net return of maize for different fertilizer management options, 12 different treatments were planned (Table 3). For the CM treatments it was assumed that the manure was broadcast on the soil surface and supplemented with $250 \mathrm{~kg} \mathrm{ha}^{-1}$ of single super phosphate (SSP), banded at a depth of $8 \mathrm{~cm}$, both at sowing. Although cattle manure includes phosphorus that meets maize crop needs, about $3 / 4$ of its content is in a form not readily usable by plants (Cassol et al., 2001), requiring supplementation with a more soluble source of phosphorus. Cattle manure rates for treatments T4, T5 and T6 were determined as to have equivalence, with respect to nitrogen, with conventional mineral fertilization. For simulation purposes, the average nitrogen content of cattle manure was assumed to be $20 \mathrm{~kg} \mathrm{t}^{-1}$ (Oliveira et al., 2004). The model was set to use the Godwin \& Singh (1998) approach to simulate 


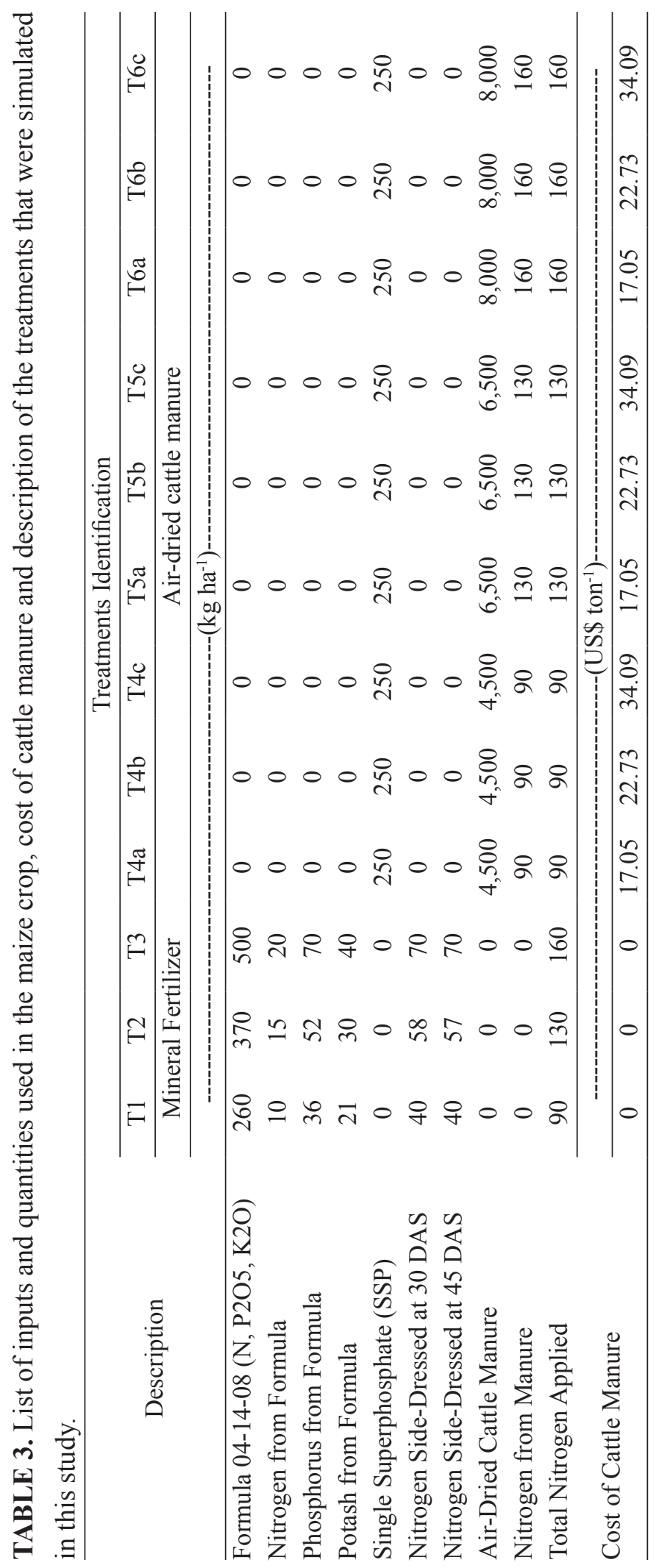

the dynamics of organic matter for each layer of the soil profile.

For net return analysis, a maize crop production cost spreadsheet, developed by the Minas Gerais State Extension Service, EmaterMG, was adapted to account for the higher technology production system that was employed. It was considered that even for family farms an improved production technology system would be recommended, including soil correction with dolomitic lime every three years and technical assistance to aid family farmers for implementing this production system.

The quantities of the supplies and services with associated minimum, mode and maximum costs were used to compute the basic production costs, which were common to all treatments (Table 4). The minimum, mode and maximum costs of the mineral fertilizer components, nitrogen $(\mathrm{N})$, phosphorus $\left(\mathrm{P}_{2} \mathrm{O}_{5}\right)$ and potash $\left(\mathrm{K}_{2} \mathrm{O}\right)$, as well as, the price of maize grain are shown in Table 5. The cost of supplies and services were drawn from a series of 22 values obtained from February 2005 to May 2010 as provided by the Secretariat of Agriculture and Supply of Paraná State, Brazil, SEAB ${ }^{1}$. For the price of maize grain, the minimum, mode, and maximum prices were obtained from a series that consisted of 79 weekly values starting on January $2^{\text {nd }}, 2009$ and ending on June $25^{\text {th }}, 2010$ at Uberlândia MG, Brazil, the closest maize market place ${ }^{2}$.

${ }^{1}$ PARANÁ. Secretaria de Estado da Agricultura e do Abastecimento do Paraná. Departamento de Economia Rural. Planilha de custo de insumos e serviços. Available at: <http://www.seab.pr.gov.br/>. Access on: April 27, 2011.

${ }^{2}$ AGROLInK. Preço de milho em Uberlândia, MG, Brasil. Available at: <http://www.agrolink.com.br/cotacoes/Cotacoes.aspx $>$. Access on: April 26, 2011. 
TABLE 4. Quantities per hectare and minimum, mode and maximum values of crop inputs and services, common to all treatments, used for net return analysis of the maize production system.

\begin{tabular}{lccccc}
\hline \multirow{2}{*}{ Description $^{1}$} & \multirow{2}{*}{ Unit } & Quantity per ha & \multicolumn{3}{c}{ Market Price $^{(2)}$ (US\$) } \\
\cline { 5 - 6 } Seeds, BRS 1030 & & & Minimum & Mode & Maximum \\
Herbicide Nicosulfuron & $\mathrm{kg}$ & 1 & 70.62 & 80.57 & 97.56 \\
Insecticide Decis 200 SC & $\mathrm{L}$ & $\mathrm{L}$ & 31.90 & 39.29 & 73.09 \\
Ploughing & Tractor hour & 1 & 4.31 & 4.84 & 10.81 \\
Harrowing & Tractor hour & 1 & 29.69 & 37.63 & 44.64 \\
Herbicide Application & Tractor hour & 0.3 & 29.69 & 37.63 & 44.64 \\
Sowing & Tractor hour & 0.8 & 8.91 & 11.29 & 13.39 \\
Nitrogen Side-Dressing & Tractor hour & 1 & 23.75 & 30.10 & 35.72 \\
Insecticide Application & Tractor hour & 0.3 & 29.69 & 37.63 & 44.64 \\
Helper & Man-day & 1.5 & 11.34 & 15.88 & 20.00 \\
Hand Harvest & Man-day & 10 & 97.22 & 136.08 & 171.42 \\
Internal Transportation & Tractor hour & 0.5 & 14.85 & 18.82 & 22.32 \\
Dolomitic Lime & Ton & 2 & 18.81 & 21.31 & 23.59 \\
Lime Transportation & Ton & 2 & 4.39 & 6.44 & 6.44 \\
Lime Distribution & Tractor hour & 1 & 9.90 & 12.55 & 14.88 \\
Technical Assistance & \% & 2 & 7.88 & 10.03 & 12.73 \\
\hline Total & & & 401.84 & 511.37 & 649.27 \\
\hline
\end{tabular}

${ }^{1}$ Rates used and costs of cattle manure were described in the Table 3; rates and costs of mineral fertilizer were described in Table 3 and Table 5. ${ }^{2}$ Cost of supplies and services were drawn from a series with 22 values from February 2005 to May 2010 (PARANÁ. Secretaria de Estado da Agricultura e do Abastecimento do Paraná. Departamento de Economia Rural. Planilha de custo de insumos e serviços. Available at: <http://www.seab.pr.gov.br/>. Access on: April 27, 2011); values in Brazilian reais (R\$) were converted to US dollars (US\$) by using the average rate of R\$ 1.76 per US\$ 1.00, for year 2010 (BANCO CENTRAL DO BRASIL. Taxa de câmbio. Available at: <http://www4.bcb.gov.br/pec/taxas/port/PtaxRPesq.asp?idpai=TXCOTACAO>. Access on: April 26, 2011).

A survey was held on October 24, 2010 at the Bela Vista Ranch, a typical family farm operation located in the city of Fortuna de Minas (MG), Brazil, to determine cattle manure costs. This farm currently uses cattle manure as fertilizer in a 1.5 ha maize field. According to the rancher, the cost per ton of air-dried cattle manure was US\$ 17.04, taking into consideration the man-hours required to collect the manure that accumulates in the barn used for milk production. Since this seems too low as compared to average cattle manure cost provided by $\mathrm{SEAB}^{1}$, additional treatments were simulated with costs of US\$ 22.73 and US\$ 34.09 per ton of air-dried cattle manure. The treatments T4, T5 and T6 were then split into three subtreatments identified as "a", "b", and "c" (Table 3). The cost of applying $250 \mathrm{~kg} \mathrm{ha}^{-1}$ of single superphosphate (SSP) at sowing was also added to each cattle manure treatment.

All cost and price values were converted from Brazilian currency reais (R\$) to US dollar (US\$) by 
using an average conversion factor of 1.76 reais per dollar for $2010^{3}$. Cost data were then entered as input in the economic module of the seasonal analysis

${ }^{3}$ BANCO CENTRAL DO BRASIL. Taxa de câmbio. Available at: $<$ http:// www4.bcb.gov.br/pec/taxas/port/PtaxRPesq.asp?idpai=TXCOTACAO $>$. Access on: April 26, 2011. program of DSSAT. Additionally, the production costs, as shown in tables 4 and 5, and the cattle manure costs were combined to generate the final production costs for maize computed as minimum, mode and maximum for each treatment as shown in Table 6 .

TABLE 5. Minimum, mode and maximum market maize grain price and nitrogen, phosphorus and potash fertilizers costs.

\begin{tabular}{lcccc}
\hline \multirow{2}{*}{ Description } & Corn Grain $^{1}$ & Nitrogen $^{2}$ & Phosphorus $^{2}$ & Potash $^{2}$ \\
\cline { 2 - 4 } & (US\$ per 60 kg bag) & $\mathrm{N}$ & $\mathrm{P}_{2} \mathrm{O}_{5}$ & $\mathrm{~K}_{2} \mathrm{O}$ \\
\hline \multirow{2}{*}{ Minimum } & 8.81 & 1.11 & $\left(\mathrm{US} \mathrm{kg} \mathrm{kg}^{-1}\right)$ & $\left(\mathrm{US} \mathrm{kg}^{-1}\right)$ \\
Mode & 9.38 & 1.42 & 1.11 & 1.11 \\
Maximum & 11.65 & 2.77 & 1.42 & 1.42 \\
\hline
\end{tabular}

${ }^{1}$ Maize minimum, mode and maximum grain prices derived from a series with 79 weekly values from January 02 to June 25,2010 at the city of Uberlândia, MG, Brazil (AGROLINK. Preço de milho em Uberlândia, MG, Brasil. Available at: <http://www.agrolink. com.br/cotacoes/Cotacoes.aspx>. Access on: April 26, 2011). ${ }^{2}$ Costs of nitrogen, phosphorus and potash are proportional to their concentration in the formula 04-14-08 and were drawn from a series with 22 values from February 2005 to May 2010 (PARANÁ. Secretaria de Estado da Agricultura e do Abastecimento do Paraná. Departamento de Economia Rural. Planilha de custo de insumos e serviços. Available at: <http://www.seab.pr.gov.br/>. Access on: April 27, 2011).

TABLE 6. Minimum, maximum and mode values for maize production cost, for different treatments with conventional mineral fertilizer (MF) and cattle manure (CM).

\begin{tabular}{cccc}
\hline \multirow{2}{*}{ Treatments $^{1}$} & \multicolumn{3}{c}{ Description } \\
\cline { 2 - 4 } & Minimum & Mode & Maximum \\
\hline T1 & Maize Production Cost $\left(\mathrm{USS} \mathrm{ha}^{-1}\right)$ \\
T2 & 545.56 & 698.31 & 1032.78 \\
T3 & 617.59 & 790.57 & 1212.9 \\
T4a & 509.24 & 872.88 & 1373.79 \\
T4b & 509.24 & 630.15 & 826.68 \\
T4c & 534.81 & 655.72 & 852.24 \\
T5a & 585.95 & 706.86 & 903.38 \\
T5b & 543.34 & 664.24 & 860.77 \\
T5c & 580.27 & 701.18 & 897.70 \\
T6a & 654.13 & 775.04 & 971.56 \\
T6b & 568.90 & 689.81 & 886.34 \\
T6C & 614.36 & 735.27 & 931.79 \\
\hline
\end{tabular}

${ }^{1}$ Treatment identification and description can be found in table 3; combination of tables 3, 4 and 5 . 
Following the simulation of the scenarios using the historical series of weather data, one could generate stochastic net return values. For each fertilizer treatment, the scenarios simulations generated 49 yield and 147 (49 × 3) net return values, which were analyzed using frequency distribution and mean-variance. These results were analyzed in terms of technical and economic feasibility for a maize production system in the Central region of Minas Gerais State, Brazil.

\section{Results and Discussion}

There was a great variability in grain yield, expressed as grain dry mass, represented by the large amplitude of simulated values for each treatment (Figure 1). Considering all treatments, the simulated yield ranged from 1,124 to $7,638 \mathrm{~kg} \mathrm{ha}^{-1}$, indicating the strong effect of weather uncertainty on rainfed maize production in the region. When using conventional mineral fertilizer, treatment $\mathrm{T} 3$ provided the best result with a median yield of $5,768 \mathrm{~kg} \mathrm{ha}^{-1}$. Among the treatments fertilized with cattle manure, T6, with an average yield of $5,403 \mathrm{~kg} \mathrm{ha}^{-1}$, performed the best. Both T3 and T6 provided the largest amount of nitrogen to the crop at a rate of $160 \mathrm{~kg} \mathrm{ha}^{-1}$. Among the treatments with conventional mineral fertilizer, T1 was the one that had the lowest median yield of $4,812 \mathrm{~kg} \mathrm{ha}^{-1}$. The equivalent cattle manure treatment, considering nitrogen rate, $\mathrm{T} 4$, also showed the lowest yield of $3,857 \mathrm{~kg} \mathrm{ha}^{-1}$.

For treatments using cattle manure, the maize yield was lower, as compared to their counterparts using conventional mineral fertilizers. This is because the model considers the dynamics of soil organic

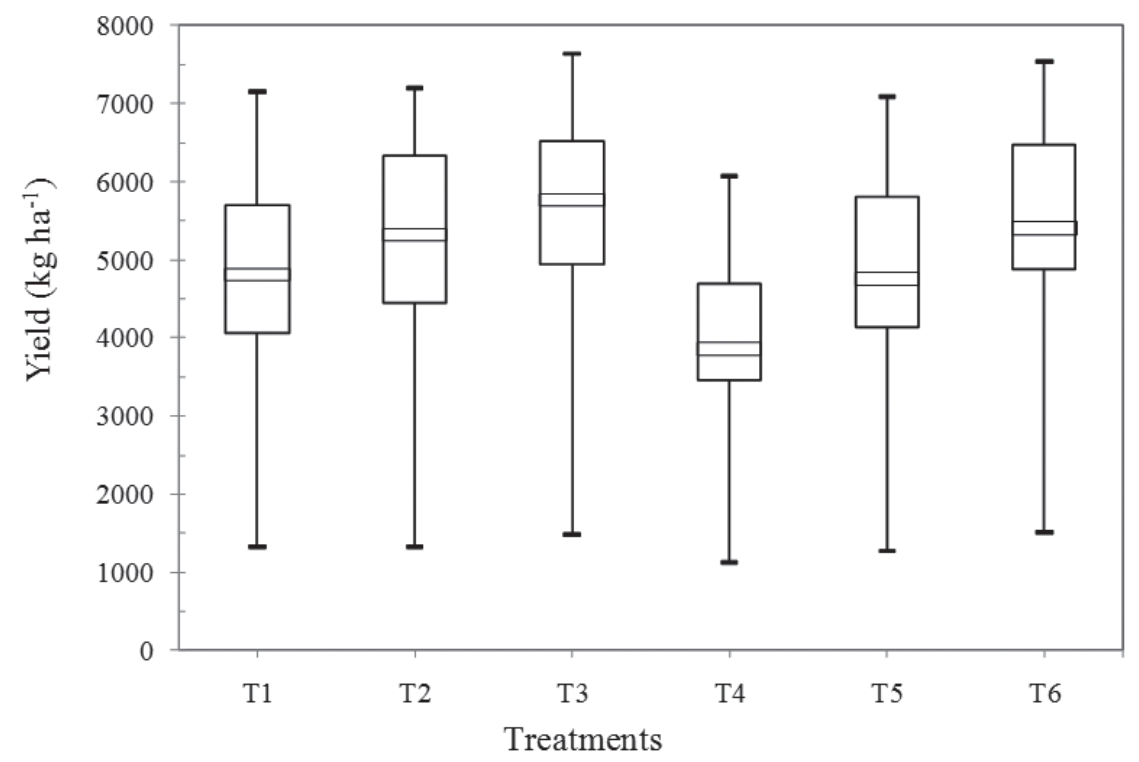

FIGURE 1. Maize yield distribution, indicating minimum, maximum, median and percentiles (25, 50 and $75 \%$ ) for different treatments with conventional fertilizer (MF) and cattle manure (CM). Treatments T1, T2 and T3 are mineral nitrogen rates of 90, 130 and $160 \mathrm{~kg} \mathrm{ha}^{-1}$, respectively, and T4, T5 and T6 are cattle manure doses that provide equivalent nitrogen rates of 90,130 and $160 \mathrm{~kg} \mathrm{ha}^{-1}$ plus $250 \mathrm{~kg} \mathrm{ha}^{-1}$ of single superphosphate, respectively. 
matter, in which nitrogen is available to plants at a slower release rate as compared to conventional mineral fertilizer (Godwin \& Singh, 1998).

For treatment T3, in $25 \%$ of the years or one in every four years, the maize yield varied from 1,486 to $4,948 \mathrm{~kg} \mathrm{ha}^{-1}$. Likewise for $25 \%$ of the years, yield varied from 6,523 to $7,638 \mathrm{~kg} \mathrm{ha}^{-1}$. In other words, there is a $50 \%$ chance that a farmer obtains either the lowest or the highest yield for any given year. In 50\% of the years or every other year, yield varied from 4,948 to $6,523 \mathrm{~kg} \mathrm{ha}^{-1}$. For T6, in $25 \%$ of the years maize yield varied from 1,513 to $4,883 \mathrm{~kg} \mathrm{ha}^{-1}$ and for $25 \%$ of the years yield varied from 6,473 to $7,537 \mathrm{~kg} \mathrm{ha}^{-1}$ in good years. In $50 \%$ of the years, one would expect maize yields to vary from 4,883 to $6,473 \mathrm{~kg} \mathrm{ha}^{-1}$ (Figure 1).

A survey conducted by the Brazilian Geography and Statistic Institute, IBGE, found that rainfed maize yield for the county, from 2003 to 2008 , ranged from 2,969 to $4,350 \mathrm{~kg} \mathrm{ha}^{-1}$. Another study ${ }^{4}$ carried out by the State Extension Service, Emater-MG, for the 2009/2010 season indicated that the average maize rainfed yield in the region was $2,527 \mathrm{~kg} \mathrm{ha}^{-1}$. These figures are lower than the 4,812 $\mathrm{kg} \mathrm{ha}^{-1}$ simulated yield obtained with low nitrogen input treatment, T1, pointing out that there is room for maize yield improvement by simply using appropriate management practices, including higher fertilizer rates.

The treatments with similar high nitrogen rates, i.e., T3 and T6, also had the highest average yield of 5,680 and 5,511 $\mathrm{kg} \mathrm{ha}^{-1}$, respectively (Figure 2). Treatments that had the lowest average yield were T1 and T4 with yields of 4,869 and 4,106 $\mathrm{kg} \mathrm{ha}^{-1}$, respectively. As expected and independent of the source of either conventional mineral fertilizer or cattle manure, the higher the nitrogen rate tested, the higher the yield (Figure 2).

${ }^{4}$ AVALIAÇÃO de sistemas de produção na região central de Minas Gerais. Sete Lagoas: Emater-MG, 2010. Concurso de eficiência produtiva na cultura do milho.

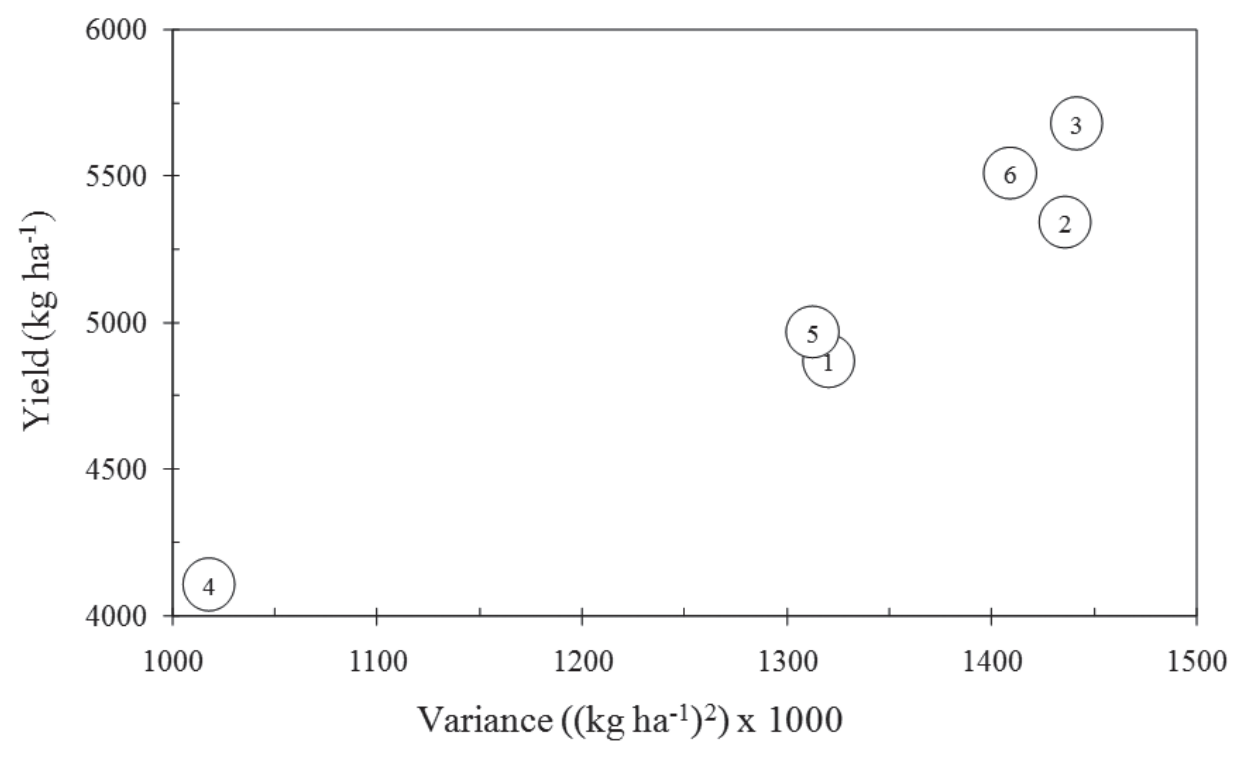

FIGURE 2. Average yield variance for different treatments with conventional mineral fertilizer (MF) and cattle manure (CM). Circles indicate the treatments T1, T2 and T3 that are mineral nitrogen rates of 90, 130 and $160 \mathrm{~kg} \mathrm{ha}^{-1}$, respectively, and T4, T5 and T6 are cattle manure doses that provide equivalent nitrogen rates of 90,130 and $160 \mathrm{~kg} \mathrm{ha}^{-1}$, plus $250 \mathrm{~kg} \mathrm{ha}^{-1}$ of single superphosphate, respectively. 
Gomes et al. (2005) found that yield increased linearly with rates of $0,10,20$ and $40 \mathrm{~m}^{3} \mathrm{ha}^{-1}$ of cattle manure when they evaluated the effect of organic and mineral fertilizers on maize production in Coimbra, MG, Brazil, during the 1990/1992 and 1991/1992 cropping seasons. There was also an increase in yield with higher rates of mineral fertilizer. Yield was $25 \%$ and $43 \%$ higher for 250 and $500 \mathrm{~kg} \mathrm{ha}^{-1}$ of the formula 4-14-8, respectively, compared to the control treatment without mineral fertilizer. Gomes et al. (2005) also noticed that the use of organic compound at a rate of $40 \mathrm{~m}^{3} \mathrm{ha}^{-1}$ showed similar yield as the treatment that used $500 \mathrm{~kg} \mathrm{ha}^{-1}$ of the 4-14-8 formula.

We also found that a higher nitrogen rate, independent of the source of $\mathrm{N}$, increased the interannual variability, expressed by the higher simulated yield variance (Figure 2). In years with favorable weather, the crop responded to higher nitrogen levels, producing higher yields. With low nitrogen rates, even in favorable years, the maize hybrid did not develop its genetic potential, resulting in large amplitude between maximum and minimum simulated yield. A large variability of maize response to nitrogen fertilization as a consequence of weather instability was observed in long-term field trials that tested different combinations and rates of mineral fertilizer, manure and stover in China (Wang et al., 2010) and also in a study carried out with CERESMaize model in Africa (Jagtap et al., 1999).

As might be expected, the optimum economic results were different from the optimum yield levels (Figure 3). When comparing the conventional

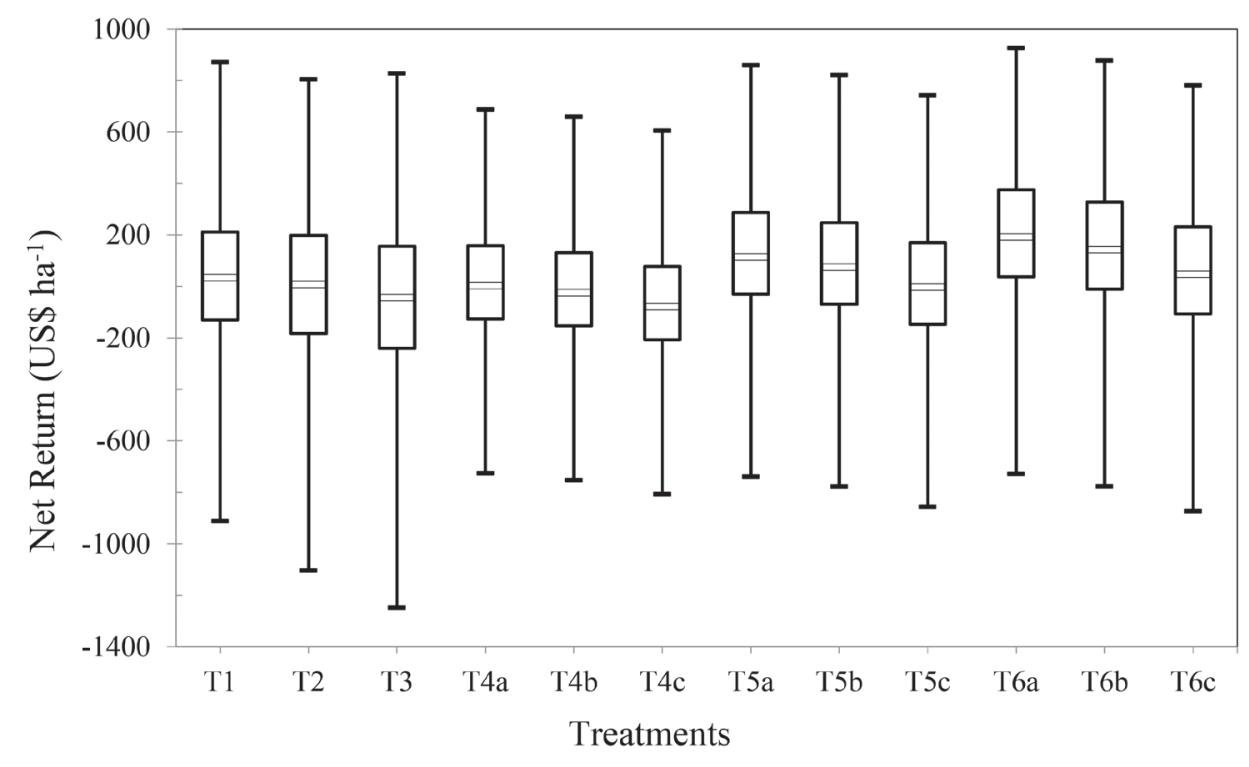

FIGURE 3. Net return frequency distribution, indicating minimum, maximum, median and percentiles $(25$, 50 and $75 \%$ ) for different treatments with conventional mineral fertilizer (MF) and cattle manure (CM). Treatments T1, T2 and T3 are mineral nitrogen rates of 90, 130 and $160 \mathrm{~kg} \mathrm{ha}^{-1}$, respectively, and T4, T5 and

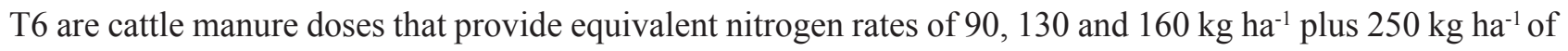
single superphosphate, respectively. The letters "a" in the treatments T4, T5 and T6 indicates a cattle manure cost of 17.05 US\$ ton ${ }^{-1}$, "b" indicates a cost of 22.73 US\$ ton ${ }^{-1}$ and "c" indicates a cost of 34.09 US\$ ton ${ }^{-1}$. 
mineral fertilizer (MF) treatments, it can be seen that the median return of US\$ $31.31 \mathrm{ha}^{-1}$ was slightly higher for $\mathrm{T} 1$ as compared to the treatment that used higher nitrogen rates. In $25 \%$ of the years one can expect economic losses ranging from US\$ 122.73 to US\$ 861.59 per hectare. Every other year, net returns ranged from a US\$ 122.73 loss to a US\$ 199.83 profit per hectare (Treatment T1 in Figure 3). Given the high weather variability in the region, the simulations indicated that if no weather forecast is available, it is preferable for a farmer to use a lower nitrogen rate to secure even a minimal profit.

When using cattle manure (CM) as fertilizer, a higher net return was achieved with $8.0 \mathrm{t} \mathrm{ha}^{-1}$ rate, at a cost of US\$ $17.04 \mathrm{t}^{-1}$ (T6a). Contrary to some farmers' belief, the higher the manure cost, the greater the rate required to ensure a higher yield and, consequently, a higher profitability. Maize grown with only $4.5 \mathrm{t} \mathrm{ha}^{-1}$ of cattle manure can result in an economic loss when the cost of manure exceeds US\$ $17.04 \mathrm{t}^{-1}$ (Figure 3).

For the treatment that used $8.0 \mathrm{t} \mathrm{ha}^{-1}$ of cattle manure, at a cost of US\$17.04 $\mathrm{t}^{-1}$ (T6a), it is expected that in $25 \%$ of the years the net return can range from a loss of US\$ 688.29 per hectare to a profit of US\$ 35.11 per ha. Under good weather conditions during $25 \%$ of the years, one can expect profits ranging from US\$ 354.83 to US\$ 875.06 per hectare. In 50\% of the years, one can get profits ranging from US\$ 35.11 to US\$ 354.83 per hectare (Figure 3). These results indicate that it is fundamental to advance the research related to weather and climate forecasting to allow farmers to make crop management decisions that ensure some profitability for maize production system in this region of Brazil.

A survey conducted at Bela Vista Ranch, city of Fortuna de Minas, MG, Brazil, indicated that the approximate cost for cattle manure was US\$ 17.04 per ton of air-dried material. The rancher uses the manure as fertilizer in maize production, but does not obtain the return predicted by the model. One of the main reasons is the improper production technology, such as low inputs, poor weed control and the use of a low yielding hybrid. The simulations showed, however, that with adequate management it is possible to obtain a good maize yield with excellent profitability. Decision support systems that incorporate the outcomes of crop simulations modes (Fraisse et al, 2006; Paz et al., 2007), therefore, can be used by the extension service to develop advisories for improvement of maize production in the region, whose average yield in 2009/2010 season ${ }^{5}$ was only $2,527 \mathrm{~kg} \mathrm{ha}^{-1}$. Incorporating weather forecasts with the crop simulation models also has shown benefits (Soler et al., 2007).

The average net return among the different treatments with conventional mineral fertilizer (MF) and cattle manure (CM) ranged from a loss of US\$ 62.84 to a profit of US\$ 183.53 per hectare (Figure 4). One can observe that, for treatments with conventional mineral fertilizer (T1, T2 and T3) the average net return decreased as the nitrogen fertilizer rate increased. In addition, the variability of the net return increased due to a better crop response under good weather conditions (Figure 4). The variability was considerably greater in treatments that used conventional mineral fertilization, because they reflect the variability in mineral nitrogen fertilizer costs, whereas in treatments with cattle manure, the cost of this input was fixed for all simulated years. The different levels of variability observed in net return values for treatments with cattle manure arise mainly from uncertainties in weather conditions. Higher manure rates generated greater variability since in favorable years the maize crop responded 
to higher soil nitrogen availability, resulting in an increase in the yield amplitude (Figure 4).
A rate of $90 \mathrm{~kg} \mathrm{ha}^{-1}$ of conventional mineral fertilizer provided the best median return of US\$

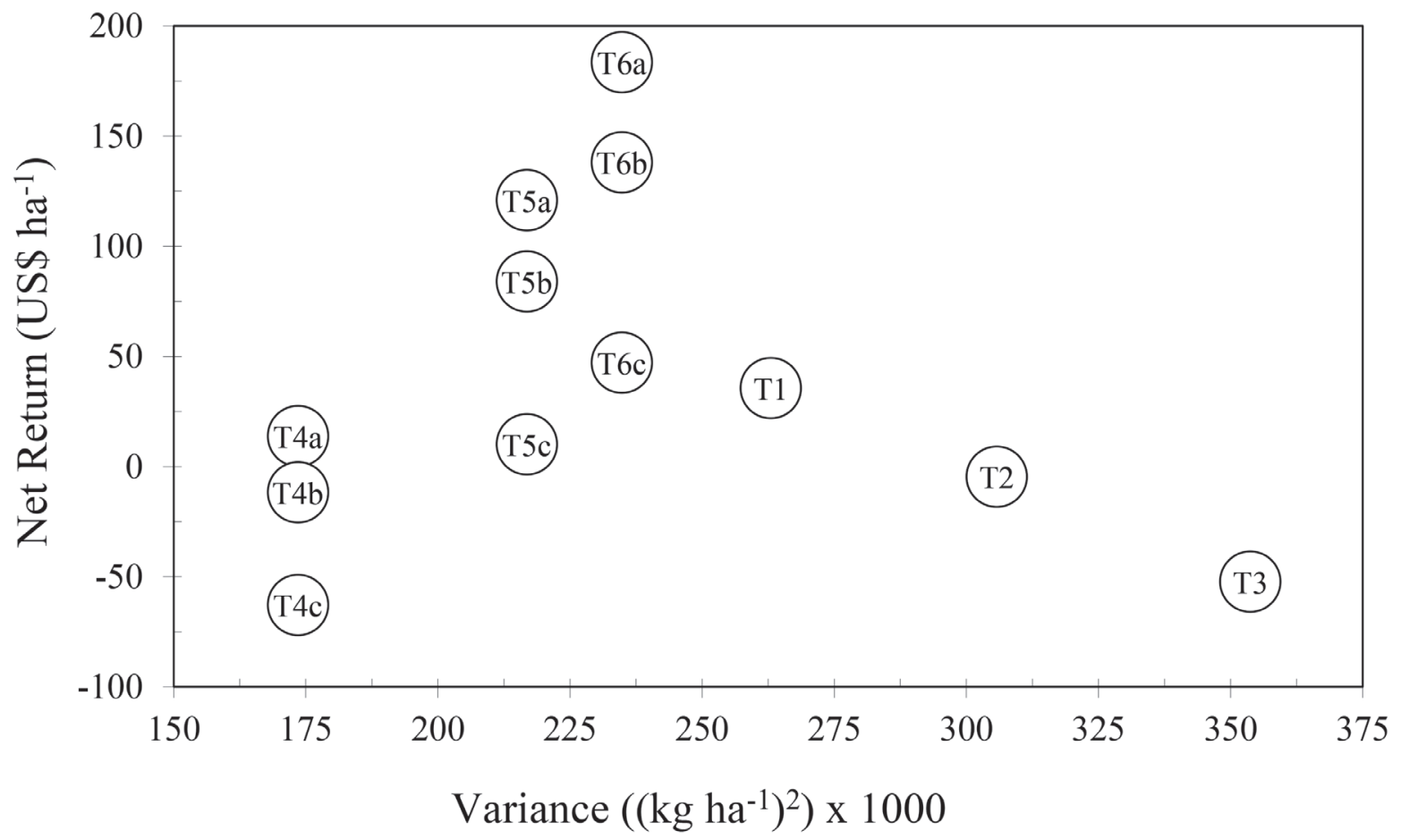

FIGURE 4. Average net return variance for different treatments with conventional mineral fertilizer (MF) and cattle manure (CM). Circles indicate the treatments T1, T2 and T3 that are mineral nitrogen rates of 90, 130 and $160 \mathrm{~kg} \mathrm{ha}^{-1}$, respectively, and T4, T5 and T6 are cattle manure doses that provide equivalent nitrogen rates of 90,130 and $160 \mathrm{~kg} \mathrm{ha}^{-1}$, plus $250 \mathrm{~kg} \mathrm{ha}^{-1}$ of single superphosphate, respectively.

\section{Conclusions}

High interannual variability was observed in the rainfed maize yield, for all fertilizer sources and rates used. The higher the nitrogen rate employed, the greater the variability.

Independent of the source of fertilizer used, the higher the nitrogen rate applied, the higher the average yield. A rate of $160 \mathrm{~kg} \mathrm{ha}^{-1}$ of nitrogen coming from conventional mineral fertilizer provided a median yield of $5,768 \mathrm{~kg} \mathrm{ha}^{-1}$, while the same rate coming from cattle manure yielded $5,403 \mathrm{~kg} \mathrm{ha}^{-1}$.
31.31 per hectare, as compared to the rates 130 and $160 \mathrm{~kg} \mathrm{ha}^{-1}$. The highest average profit of US\$ 183.53 per hectare was obtained with $8.0 \mathrm{t} \mathrm{ha}^{-1}$ of cattle manure, at a cost US\$ 17.04 per ton. The higher the cost of manure, the greater must be the rate used, in order to obtain a better profitability.

Independent of the source of nitrogen used, farmers in the Central Region of Minas Gerais State, Brazil, can expect yield break and negative net return for the rainfed maize production in one out of every four years, mainly as a consequence of weather instabilities. 


\section{Acknowledgements}

The authors would like to acknowledge the National Council for Scientific and Technological Development, $\mathrm{CNPq}$, for providing financial support through the project "Net return Analysis of Alternative Fertilizer Sources for Family Farm", process number 574975/2008-0, and Emater-MG, for mediating the contact with farmer and providing the spreadsheet template for maize production cost calculation.

\section{References}

AMARAL, T. A.; ANDRADE, C. L. T.; OLIVEIRA, A. C.; SILVA, D. F.; SANTANA, C. B.; MOURA, B. F.; CASTRO, L. A. Metodologia para o estabelecimento do período de semeadura de milho. Sete Lagoas: Embrapa Milho e Sorgo, 2009. 13 p. (Embrapa Milho e Sorgo. Documentos, 88).

ASSMANN, T. S.; ASSMANN, A. L.; SOARES, A. B.; CASSOL, L. C.; GIASSON, M. S.; GIASSON, N. F. Fixação biológica de nitrogênio por plantas de trevo (Trifolium spp) em sistema de integração lavoura-pecuária no Sul do Brasil. Revista Brasileira Zootecnia, Vicosa, MG, v. 36, p. 1435-1442, 2007.

BORTOLINI, C. G.; SILVA, P. R. F. ARGENTA, G.; FORSTHOFER, E. L. Rendimento de grãos de milho cultivado após aveia-preta em resposta a adubação nitrogenada e regime hídrico. Pesquisa Agropecuária Brasileira, Brasilia, DF, v.36, p.1101-1106, 2001

BULL, L. T. Nutrição mineral do milho. In: BULL, L. T.; CANTARELLA, H. (Ed.). Cultura do milho: fatores que afetam a produtividade. Piracicaba: Potafos, 1993. p. 63-146.

CASSOL, P. C.; GIANELlO, G.; COSTA, V. E. U. Frações de fósforo em estrumes e sua eficiência como adubo fosfatado. Revista Brasileira Ciência do Solo, Campinas, v. 25, p. 635-644, 2001.
FRAISSE, C. W.; BREUER, N. E.; ZIERDEN, D.; BELLOW, J. G.; PAZ, J.; CABRERA, V. E.; GARCIA y GARCIA, A.; INGRAM, K. T.; HATCH, U.; HOOGENBOOM, G.; JONES, J. W.; O’BRIEN, J. J. AgClimate: A climate forecast information system for agricultural risk management in the southeastern USA. Computers and Electronics in Agriculture, Amsterdam, v. 53, p. 13-27, 2006.

GODWIN,D.C.;SINGH,U.Nitrogenbalanceandcropresponse to nitrogen in upland and lowland cropping systems. In: TSUJ, G. Y.; HOOGENBOOM, G.; THORNTON, P. K. Understanding options for agricultural production. Dordrech: Kluwer, 1998. p. 55-77. GOMES, J. A.; SCAPIM, C. A.; BRACCINI, A. L.; FILHO, P. S. V.; SAGRILO, E.; MORA, F. Adubações orgânica e mineral, produtividade do milho e características físicas e químicas de um Argissolo Vermelho-Amarelo. Acta Scientiarum Agronomy, Maringa,v. 27, p. 521-529, 2005.

NOVO retrato da agricultura familiar: o Brasil redescoberto. Brasília, DF: Ministério do Desenvolvimento Agrário-INCRA/ FAO, 2000. 73 p. HOFFMANN, F.; RITCHIE, J. T. Model for slurry and manure in CERES and similar models. Journal of Agronomy and Crop Science, Weinheim, v. 170, p. 330-340, 1993.

HOOGENBOOM, G.; JONES, J. W.; WILKENS, P. W.; PORTE, C. H.; HUNT, L. A.; BOOTE, K. J.; SINGH, U.; URYSEV, O.; LIZASO, J. I.; WHITE, J. W.; OGOSHI, R.; GIJSMAN, A. J.; BATCHELOR, W. D.; TSUJI, G. Y. Decision Support System for Agrotechnology Transfer: version 4.5. Honolulu: University of Hawaii, 2009. 1 CD-ROM.

IBGE. Censo Agropecuário 2006. Disponível em: <http:// www.sidra.ibge.gov.br>. Acesso em: 19 mar. 2012.

JAGTAP, S. S.; ABAMU, F. J.; KLING, J. G. Long-term assessment of nitrogen and variety technologies on attainable maize yields in Nigeria using CERES-maize. 
Agricultural Systems, Essex, v. 60, p. 77-86, 1999. JONES,J.W.;HOOGENBOOM,G.;PORTER,C.H.;BOOTE, K. J.; BATCHELOR, W. D.; HUNT, L. A.; WILKENS, P. W.; SINGH, U.; GIJSMAN, A. J.; RITCHIE, J. T. DSSAT cropping system model. European Journal of Agronomy, Amsterdam, v. 18, p. 235-265, 2003. KIEHL, E. J. Fertilizantes orgânicos. São Paulo: Agronômica Ceres, 1985. 492 p.

KONZEN, E. A. Manejo e utilização de esterco de bovinos. Sete Lagoas: Embrapa Milho e Sorgo, 1999. (Embrapa Milho e Sorgo. Comunicado Técnico, 14)

NEVENS, F.; REHEUL, D. Agronomical and environmental evaluation of a long-term experiment with cattle slurry and supplemental inorganic $\mathrm{N}$ applications in silage maize. European Journal of Agronomy, Amsterdam, v. 22, p. 349-361, 2005.

OLIVEIRA, R. F.; TEIXEIRA, L. B.; GERMANO, V. L. C. Composto orgânico de lixo e adubos orgânicos tradicionais na produção de matéria seca de milho e na fertilidade do solo. Belém: Embrapa Amazônia Oriental, 2004. (Embrapa Amazônia Oriental. Boletim de Pesquisa e Desenvolvimento, 27)

PANOSO, L.A.A.; RAMOS, D. P.; BRANDÃO, M. Solos do campo experimental da Embrapa Milho e Sorgo: suas características e classificação no novo sistema brasileiro. Rio de Janeiro: Embrapa Solos, 2002. (Embrapa Solos. Boletim de Pesquisa e Desenvolvimento, 5) PAZ, J. O.; FRAISSE, C. W.; HATCH, L. U.; GARCIA y GARCIA, A.; GUERRA, L. C.; URYASEV, O.; BELLOW, J. G.; JONES, J. W.; HOOGENBOOM. G. Development of an ENSO-based irrigation decision support tool for peanut production in the southeastern US. Computers and Electronics in Agriculture, Amsterdam, v. 55, p. 28-35, 2007.

SANTANA, C. B.; ANDRADE, C. L. T.; AMARAL, T. A.; SILVA, D. F.; MOURA, B. F.; CASTRO, L. A. Parametrização do modelo Ceres-Maize para cultivares de milho. In: SEMINÁRIO DE INICIAÇÃO CIENTÍFICA PIBIC/BIC JÚNIOR, 1., 2010, Sete Lagoas. [Trabalhos apresentados]. Sete Lagoas: Embrapa Milho e Sorgo, 2010. 1 CD-ROM.

SCHRÖDER, J. Revisiting the agronomic benefits of manure: a correct assessment and exploitation of its fertilizer value spares the environment. Bioresource Technology, Essex, v. 96, p. 253-261, 2005.

SHAYYA, W. H.; BERNUTH, R. D.; RITCHIE, J. T.; PERSON, H. L. A simulation model for land application of animal manure. St. Joseph: American Society of Agricultural Engineers, 1993. 26 p. (Paper n. 93-2012) SILVA, E. C.; BUZETTI, S; LAZZARINI, E. Aspectos econômicos da adubação nitrogenada na cultura do milho em sistema plantio direto em Latossolo Vermelho distroférrico fase cerrado. Revista Brasileira de Milho e Sorgo, Sete Lagoas, v. 4, p. 286-297, 2005.

SILVA, J.; SILVA, P. S. L.; OLIVEIRA, M.; SILVA, K. M. B. Efeito de esterco bovino sobre os rendimentos de espigas verdes e de grãos de milho. Horticultura Brasileira, Brasilia, DF, v. 22, p. 326-331, 2004.

SOLER, C. M. T.; SENTELHAS, P. C.; HOOGENBOOM, G. Application of the CSM-CERES-Maize model for planting date evaluation and yield forecasting for maize grown off-season in a subtropical environment. European Journal of Agronomy, Amsterdam, v. 27, p. 165-177, 2007.

SOUSA, D. M. G. de; LOBATO, E. (Ed.). Cerrado: correção do solo e adubação. Planaltina: Embrapa Cerrados, 2004. $416 \mathrm{p}$.

WANG, X.; KUAI, D.; YAN, W.; XIAOMIN, Z.; QUANSHENG, Z.; XUEPING, W.; DIANXIONG, C.; HOOGMOEDC, W. B.; OENEMA, O. Nutrient management adaptation for dryland maize yields and water use efficiency to long-term rainfall variability in China. Agricultural Water Management, Amsterdam, v. 97, p. 1344-1350, 2010. 